\title{
TASAWUF FALSAFI
}

Oleh: Abrar M. Dawud Faza, MA

\begin{abstract}
Philosophical Sufism has emerged clearly in Islamic treasures since the sixth century Hijrah even though the characters were only known later in the century. Since then, this type of Sufism lived and developed, especially among Sufis who were also philosophers, until near lately. The existence of a combination of Sufism and philosophy in philosophical Sufism teachings led to the teachings of Sufism of this type mixed with a number of philosophical teachings outside of Islam, such as Greece, Persia, India, and Christianity. However, his originality as Sufism still does not disappear.
\end{abstract}

Keywords: Sufism, Philosophy

\section{Pendahuluan}

Melakukan studi terhadap tasawuf merupakan pekerjaan yang tidak mudah dilakukan secara komprehensif disebabkan pembahasannya begitu luas mencakup banyak aspek. Seperti pendapat Annemarie Schimmel bahwa pembahasan tasawuf tidak saja mencakup aspek historis maupun fenomenologis saja, namun juga meliputi aspek subjektivitas yang tidak terpisahkan dengan kedua aspek sebelumnya. ${ }^{1}$

Kemungkinan inilah yang membedakan antara pengamalan tasawuf dan ilmu tasawuf sebagai salah satu cabang ilmu keislaman yang menekankan dimensi batin atau spiritual sehingga aspek lahiri sering dikaburkan atau malah dianggap tidak benar. Karena sering dinyatakan bahwa tasawuf lebih menekankan aspek ruhaniahnya dari pada aspek jasmaniahnya, atau tasawuf lebih menekankan pada kehidupan akhirat dari pada dunianya, dan lebih menekankan aspek esoteris (bathiniyah), dari pada aspek eksoteris (lahiriyah).

Berdasarkan argumentasi tersebut, di kalangan sufi dapat diamati adanya 2 (dua) tujuan pokok tasawuf. Pertama, kesucian jiwa untuk menghadap Tuhan sebagai zat yang Maha Suci melalui usaha pencarian

${ }^{1}$ Annemarie Schimmel, Dimensi Mistik dalam Islam, Terj. S. Djoko Damono dkk. (Jakarta, Pustaka Firdaus, 2003), h. xv, 1. 
jalan ketuhanan. Kedua, upaya pendekatan diri secara individual kepada Tuhan melalui serangkaian ritual tertentu. ${ }^{2}$

Untuk mewujudkan cita-cita tersebut para sufi mempunyai pemahaman, konsepsi, dan bahkan ritual yang berbeda-beda dan di dalam perbedaan tersebut membentuk karakter-karakter tertentu sehingga salah satu dampaknya melahirkan 2 (dua) tipe atau corak tasawuf, yaitu tasawuf falsafi dan tasawuf sunni.

Tasawuf falsafi adalah tasawuf yang ajaran-ajaran dan konsepsinya disusun secara mendalam dengan bahasa-bahasa yang simbolik-filosofis. Sehingga tidak heran apabila mayoritas sufi yang mempunyai paham tasawuf ini mengalami sikap ekstasi (kemabukan spiritual) dan mengeluarkan statement yang terkesan tidak awam (syathahat). Seperti yang diucapkan Ibn 'Arabi dengan slogan "Ana al-Haqd". Tokoh-tokoh lainnya antara lain Abu Yazid al-Busthami, al-Hallaj, Ibn 'Arabi, al-Jilli dan sebagainya. ${ }^{3}$

Sedangkan tasawuf Sunni adalah tasawuf yang dianggap sesuai dengan ajaran al-Qur'an dan Sunnah Nabi Saw., maksudnya peningkatan kualitas diri kepada Allah terlebih dahulu seorang calon sufi harus memahami syari'at dengan sebaik-baiknya, misalnya ia harus mempelajari fikih dalam segala bidangnya secara baik dan benar sesuai dengan ajaran yang telah dirumuskan oleh madzhab al-arba'ah. Tasawuf ini mendasarkan pengalaman kesufiannya dengan pemahaman yang sederhana dan dapat dipahami oleh manusia pada umumnya. Tokohtokoh tasawuf sunni yang populer adalah al-Junaid al-Baghdadi, alQusyairi, dan al-Ghazali, dan dalam perkembangannya tasawuf sunni mengambil bentuk praktis berupa tarekat dan ketiga tokoh inilah yang lebih banyak mengilhami dasar-dasar ajaran tarekat yang ada sekarang ini. $^{4}$

86.

'Lihat Amin Syukur, Tasawuf Kontekstual (Yogyakarta: Pustaka Pelajar, 2003), h.

'Teori-teori yang dilahirkan para tokoh tersebut seperti teori fana', baqa', dan ittihad yang dicetuskan oleh al-Busthami, teori hulul yang dipelopori oleh al-Hallaj, teori wahdatul wujud yang digawangi oleh Ibnu 'Arabi, dan teori insan kamil yang dirumuskan oleh al-Jilli. M. Sholihin, Melacak Pemikiran Tasawuf di Nusantara, (Jakarta: Raja Grafindo Persada, 2005), h. 10.

${ }^{4}$ Asmaran As., Pengantar Studi Tasawuf, Edisi Revisi, Cet. II, (Jakarta: Raja Grafindo Persada, 2002), h. 152-153. 
Dalam tulisan ini penulis fokus membahas tipologi tasawuf falsafi, sedangkan tasawuf sunni akan dibahas pada tulisan lainnya disebabkan luasnya pembahasan kedua tipologi tasawuf tersebut.

\section{A. Pengertian}

Sekilas telah disebutkan sebelumnya bahwa tasawuf falsafi merupakan tasawuf yang ajaran-ajarannya memadukan antara pencapaian dan pencerahan mistikal dengan pemaparan bersifat rasional filosofis. Di dalamnya terkandung pemaduan antar tasawuf dan filsafat sehingga dengan sendirinya membuat ajaran-ajarannya bercampur dengan sejumlah ajaran-ajaran filsafat dari luar Islam, seperti dari Yunani, India, Persia, dan agama Nasrani. Namun orisinalitasnya sebagai tasawuf (mistis Islam) tidak hilang serta tetap berusaha menjaga kemandirian ajaran Islam terutama bila dikaitkan dengan kedudukan para sufi tasawuf falsafi beragama Islam. Tasawuf falsafi juga sering disebut dengan tasawuf teoritis karena cenderung menekankan pada aspek teori atau konsep pemikiran metafisik dengan memadukan antara filsafat dengan ketasawufan. ${ }^{5}$

Tasawuf falsafi adalah sebuah konsep ajaran tasawuf yang mengenal Tuhan (makrifat) dengan pendekatan rasio (filsafat) hingga menuju ketinggkat yang lebih tinggi, bukan hanya mengenal Tuhan saja (makrifatullah) melainkan yang lebih tinggi dari itu yaitu wihdatul wujud (kesatuan wujud). Bisa juga dikatakan tasawuf falsafi yakni tasawuf yang kaya dengan pemikiran-pemikiran filsafat. Di dalam tasawuf falsafi metode pendekatannya sangat berbeda dengan tasawuf sunni atau tasawuf salafi. Kalau tasawuf sunni dan salafi lebih menonjol kepada segi praktis ( يلمعلا ) ), sedangkan tasawuf falsafi menonjol kepada segi teoritis ( يرطنلا ) sehingga dalam konsep-konsep tasawuf falsafi lebih mengedepankan asas rasio dengan pendekatan-pendekatan filosofis yang ini sulit diaplikasikan ke dalam kehidupan sehari-hari khususnya bagi orang awam, atau bahkan bisa dikatakan mustahil. ${ }^{6}$

Para sufi falsafi memandang bahwa manusia mampu naik ke jenjang persatuan dengan Tuhan yang kemudian melahirkan konsep mistik semi-filosofis "ittihad" dan "fana'baqd" yang dibangun oleh Abu Yazid al-Busthami, konsep "hulul" yang dialami oleh Husein bin Mansur al-

\footnotetext{
${ }^{5}$ Alwi Shihab, Islam Sufistik: "Islam Pertama" dan Pengaruhnya hingga Kini di Indonesia, (Bandung: Mizan 2001), h. 120.

${ }^{6}$ Shihab, Islam Sufistik..., h. 120.
} 
Hallaj, maupun konsep tasawufnya Ibn 'Arabi yang dikenal dengan "wahdat al-wujud", konsep "isyraqiyah" yang dirumuskan oleh Suhrawardi almaqtul, al-hikmah al-muta'aliyah yang digagas oleh Mulla Shadra, dan lain sebagainya.

Tasawuf falsafi juga adalah tasawuf yang ajaran-ajarannya memadukan antara visi mistis dan visi rasional pengasasnya. Tasawuf falsafi menggunakan terminologi filosofis dalam pengungkapannya, sedangkan terminologi falsafi tersebut berasal dari bermacam-macam ajaran yang telah mempengaruhi para tokohnya seperti yang sudah disebutkan sebelumnya.

\section{B. Latar Belakang}

Pembahasan tentang asal-usul tasawuf falsafi juga merupakan persoalan yang sangat kompleks, sehingga tidak bisa dikemukakan jawaban sederhana terhadap pertanyaan tentang asal-usulnya tersebut. Beberapa kalangan orientalis yang meneliti tasawuf menyebutkan bahwa tasawuf sendiri bersumber dari luar Islam, termasuk tasawuf falsafi sebagai cabangnya juga menunjukkan perbedaan pada corak pengalaman tasawuf. Thoulk menganggap tasawuf ditimba dari sumber Majusi, Dozy mengatakan tasawuf dikenal kaum Muslim lewat orang-orang Persia; Goldziher, Palqacios dan Nicholson menisbahkan tasawuf berasal dari Kristen; Horten dan Hartman berpendapat tasawuf diambil dari India (Hindu-Budha), sementara yang lain mengungkapkan bahwa Yunani merupakan sumber tasawuf. ${ }^{7}$

Meskipun demikian, banyak ilmuwan dan para pengamat tasawuf yang dengan tegas mengemukakan bahwa sumber-sumber tasawuf secara otentik berasal dari dalam Islam sendiri. Menurut Julian Baldic, wacana-wacana Al-Quran memang sangat mendukung tasawuf. ${ }^{8}$ Spencer Trimingham secara afirmatif menyatakan Sufism was a natural development within Islam the inner doctrine of Islam, the underlying mystery of the Qur'an., ${ }^{9}$ Ibn Khaldun melalui telaah historis-sosiologisnya

7Taftazani, Sufi dari Zaman..., h. 23-29; Jamil, Cakrawala Tasawuf (Ciputat: Gaung Persada Press, 2004), h. 18-24.

${ }^{8}$ Julian Baldick, Mystical Islam an Introduction to Sufism (New York:New York University Press, 1992), h. 24-26.

9]. Spencer Trimingham, The Sufi orders in Islam (New York : Oxford University Press, 1973), h.2 
mengungkapkan bahwa tasawuf bersumber dari Islam (originated in Islam) dan mengikuti praktek-praktek muslim generasi awal. ${ }^{10}$

Selanjutnya pendapat sebagian ilmuwan Muslim kontemporer, seperti Seyyed Hassein Nasr menjelaskan bahwa kehidupan spiritual kaum Sufi berawal dari Nabi Saw, di mana jiwa Nabi Saw. disinari cahaya Allah Swt. berupa Alquran, sehingga tepat sekali bila dikatakan bahwa wahyu Alquran sebagai sumber tasawuf ${ }^{11}$. Bahkan misalnya Lynn Wilcox, seorang tokoh dan Mursyid Sufi sekaligus guru besar psikologi abad ini, dengan mengutip pendapat Abu Yazid al-Bustami, secara ekspresif dan ilustratif dia menyatakan bahwa benih tasawuf sudah ditanam pada masa Nabi Adam As. Benih-benih ini berkecambah semasa Nabi Nuh As. dan berbunga semasa Nabi Ibrahim As. Anggur pun berbentuk pada masa Nabi Musa As. dan buahnya matang pada masa Nabi Isa As. Kemudian di masa Nabi Muhammad Saw. semua itu dibuat menjadi hasil air anggur yang murni. ${ }^{12}$

Meskipun demikian, sebagian ilmuwan Muslim mengakui sejujurnya bahwa tasawuf dipengaruhi pula oleh agama dan budaya lain. Dasar dan sumber fundamental tasawuf memang Alquran, Sunnah Nabi, kehidupan para sahabat dan tabi'in, namun tanpa mengingkari fakta historis, wacana-wacana tasawuf dalam perkembangan selanjutnya telah diwarnai unsur-unsur luar, terutama tasawuf falsafi yang merupakan pengaruh Persia (Yunani) yang rasional dan filsafat India yang mistis. ${ }^{13}$

Menurut Fazlur Rahman, tasawuf falsafi ini juga terkena pengaruh Grego-gnostik dan doktrin-doktrin Kristen yang dikembangkan oleh Ibn Arabi. ${ }^{14}$ Sehingga bagaimana pun juga tidak dapat dipungkiri dalam perjalanan selanjutnya sekitar abad ke-VI dan ke-VII Hijriyah, wacanawacana tasawuf banyak yang bernuansa filosofis atau tasawuf-falsafi yang

${ }^{10}$ Ibn Khaldun, The Muqaddimah, Trans. Franz Rosenthal (Princeton: Princeton University Press, 1989), h. 358.

${ }^{11}$ Seyyed Hassein Nasr,"Al-quran sebagai Fondasi Spiritualitas Islam", Ensiklopedi Tematis Spiritualitas Is/am, terj. Rahmani Astuti, ed. Seyyed Hassein Nasr, Vol. I (Bandung: Mizan, 2003), h. 10.

${ }^{12}$ Lynn Wilcox, IImu Jiwa Berjumpa Tasawuf, terj. I.G. Harimukti Bagoesoka, (Jakarta: Serambi, 2003), h. 21, Benih Tasawuf sudah ada sejak Nabi Adam diakui pula oleh Khaja Khan; Mysticism in the World is as old as its Hills.Adam was perphaps the first mystic who had direct illumination, lihat Khaja Khan, Studies in Tasawuf (Pakistan : Lahore, 1990), h. 148.

${ }^{13}$ Komaruddin Hidayat, Wahyu di langit Wahyu di Bumi, (Jakarta: Paramadina, 2003), h. 10.

${ }^{14}$ Fazlur Rahman, Islam (Chicago: University of Chicago Press, 1979), h. 142. 
diprakarsai oleh Suhrawardi (w. 587 H), Ibn Arabi (w. 638 H), Ibn Faridh (w. $632 \mathrm{H}$ ), dan lain-lain. Pada fase ini, konsep-konsep tasawuf berkembang dan diwarnai unsur-unsur diluar Islam, khususnya filsafat Yunani, sekalipun pijakan fundamental para sufi adalah Alquran dan Sunnah. ${ }^{15}$

Tasawuf filosofis merupakan tasawuf yang ajaran-ajarannya memadukan antara pencapaian pencerahan mistikal dan pemaparan secara rasional filosofis. Terminologi filosofis tersebut berasal dari bermacam-macam ajaran filsafat, yang telah mempengaruhi para tokohtokohnya. Tasawuf filosofis ini mulai muncul dengan jelas sejak abad keenam Hijriyah, meskipun para tokohnya baru dikenal setelah seabad kemudian.

Adanya pemaduan antar tasawuf dan filsafat dalam ajaran tasawuf filosofis, dengan sendirinya telah membuat ajaran-ajarannya bercampur dengan sejumlah ajaran-ajaran filsafat di luar Islam, seperti dari Yunani, India, Persia, dan agama Nasrani. Akan tetapi orsinalitasnya sebagai tasawuf tetap tidak hilang, karena para tokohnya meskipun mempunyai latar belakang kebudayaan dan pengetahuan yang berbeda dan beraneka, sejalan dengan ekspansi Islam yang telah meluas pada waktu itu, tetap berusaha menjaga kemandirian ajaran mereka, terutama bila dikaitkan dengan kedudukan mereka sebagai umat Islam. ${ }^{16}$

Corak pemahaman tasawuf falsafi ini tumbuh dan berkembang dimulai pada abad ke-VI Hijriyah. Tasawuf yang bercorak filosofis ini cenderung dengan ungkapan-ungkapan ganjil serta bertolak dari keadaan fana', mulai tenggelam dan kelak akan muncul kembali dalam bentuk lain pada pribadi-pribadi sufi yang juga filosof Muslim pada abad ke-VI dan setelahnya.

Pada mulanya tasawuf merupakan perkembangan dari pemahaman tentang makna institusi Islam.Sejak zaman sahabat dan tabi'in, kecenderungan pandangan orang terhadap islam secara lebih analitis sudah muncul. Ajaran Islam di pandang dari dua aspek yaitu aspek lahiriyah dan batiniyah. ${ }^{17}$

Corak dari pada tasawuf falsafi tentunya sangat berbeda dengan tasawuf yang pernah diamalkan oleh masa sahabat dan tabi'in, karena

\footnotetext{
${ }^{15}$ Taftazani, Sufi ..., h. 30-47; Jamil, Cakrawala Tasawuf ..., h. 18-26.

${ }^{16}$ Taftazani, Sufi..., h. 187.

${ }^{17}$ Lihat Anwar, Rosihon. I/mu Tasawuf(Bandung, Pustaka Setia, 2006), h. 89.
} 
tasawuf ini muncul karena pengaruh filasafat Neo-Platonisme. Berkembangnya tasaawuf sebagai jalan dan latihan untuk merealisir kesucian batin dalam perjalanan menuju kedekatan dengan Allah, juga menarik perhatian para pemikir muslim yang berlatar belakang teologi dan filsafat. Dari kelompok inilah (teologi dan filsafat) tampil sejumlah kelompok sufi yang filosofis atau filosofis yang sufi. Konsep-konsep mereka yang disebut dengan tasawuf falsafi yakni tasawuf yang kaya dengan pemikiran-pemikiran filsafat. ajaran filsafat yang paling banyak dipergunakan dalam analisis tasawuf adalah Paham emanasi neo-Plotinus.

\section{Ajaran Pokok}

Pemaduan filsafat dengan tasawuf pertama kali dilakukan oleh para filsuf Muslim ketika sedang mengalami helenisme pengetahuan. Misalnya filsuf Muslim yang membahas tentang Tuhan dengan menggunakan konsep-konsep neo-plotinus seperti al-Kindi. Dalam filsafat emanasinya Plotinus disebutkan bahwa roh memancar dari diri Tuhan dan akan kembali kepada Tuhan. Di sisi lain ada Pythagoras yang menyebutkan bahwa roh masuk ke dalam tubuh manusia yang kotor tidak dapat lagi kembali ke Tuhan. Selama masih kotor, ia akan tetap tinggal di bumi dan bila ruh terus berusaha untuk membersihkan diri maka dapat kembali kepada Tuhan. Maka dari konsep ini dapat ditarik ke dalam ranah konsep tasawuf yang juga berkeyakinan bahwa penciptaan alam semesta adalah pernyataan cinta kasih Tuhan yang direfleksikan dalam bentuk empirik atau sebagai Sifat madzohir dari sifat Tuhan. Sehingga jiwa atau ruh harus kembali kepada Tuhan dan tentunya dalam keadaan yang bersih.

Secara umum tasawuf falsafi adalah tasawuf yang ajaran-ajarannya memadukan antara visi mistis dan visi rasional. Tasawuf ini menggunakan terminologi filosofis dalam pengungkapannyayang berasal dari berbagai macam ajaran filsafat yang telah mempengaruhi para tokohnya. Ajarannya tasawuf falsafi lebih mengarah pada teori-teori yang rumit dan memerlukan pemahaman yang lebih mendalam dan mengedepankan akal mereka serta ajarannya memadukan antara visi mistis dan rasional. Adapun yang termasuk kategori ajaran tasawuf falsafi adalah:

a. Fana' dan Baqa', yakni lenyapnya kesadaran dan kekal.

b. Ittihad, yaitu persatuan antara manusia dengan Tuhan.

c. Hulul, yaitu penyatuan sifat ketuhanan dengan sifat kemanusiaan.

d. Wahdah al-Wujud, yaitu alam dan Allah adalah sesuatu yang satu. 
e. Isyraq, yaitu pancaran cahaya atau iluminasi. ${ }^{18}$

\section{Fana' dan Baqa'}

Dari segi bahasa al-fana berarti hilangnya wujud sesuatu. Fana berbeda dengan al-fasad (rusak). Fana artinya tidak tampaknya sesuatu, sedangkan al-fasad atau rusak adalah berubahnya sesuatu kepada sesuatu yang lain. ${ }^{19}$

Bagi sufi, fana mempunyai banyak pengertian, misalnya diartikan sebagai keadaan moral yang luhur, sebagai definisi yang mereka berikan, yaitu fananya sifat jiwa atau sirnanya sifat-sifat yang tercela. ${ }^{20}$ Kemudian, sebagai akibat dari fana adalah baqa. Secara harfiah baqa berarti kekal, sedang menurut yang dimaksud para sufi, baqa adalah kekalnya sifat-sifat terpuji, dan sifat-sifat Tuhan dalam diri manusia.

Dalam pengalaman para sufi, fana selalu diiringi dengan baqa di mana keduanya ini merupakan kembar yang tidak dapat dipisahkan dan datang beriringan, sebagaimana dinyatakan oleh para ahli tasawuf: "Apabila tampaklah nur kebaqaan, maka fanalah yang tiada, dan baqalah yang kekal". ${ }^{21}$

Dengan demikian, dapat dipahami bahwa yang dimaksud dengan fana adalah lenyapnya sifat-sifat basyariah, akhlak yang tercela, kebodohan dan perbuatan maksiat dari diri manusia. Sedangkan baqa adalah kekalnya sifat-sifat ketuhanan, akhlak terpuji, ilmu pengetahuan dan kebersihan diri dari dosa dan maksiat untuk mencapai baqa ini perlu dilakukan usaha-usaha seperti bertaubat, berdzikir, beribadah, dan menghiasi diri dengan akhlak yang terpuji.

Sebagian orang mengisyaratkan, bahwa fana itu adalah meninggalkan sifat-sifat tercela, sedangkan baqa itu melahirkan sifat-sifat terpuji. Dengan demikian, seseorang tidak akan kosong dari kedua sifat tersebut. Tidak mungkin jika hanya didapati adanya salah satu sifat dari kedua sifat tersebut karena orang yang kosong dari sifat-sifat tercela, maka tentu akan nampak sifat-sifat terpuji. Barang siapa yang dikalahkan oleh sifat-sifat tercela, maka sifat terpuji akan tertutup. ${ }^{22}$

\footnotetext{
${ }^{18}$ Asmaran As., Pengantar Studi Tasawuf (Jakarta: Rajawali Pers, 1996), h. 132.

${ }^{19}$ Abuddin Nata, Akhlak Tasawuf (Jakarta: Grafindo Persada, 2006), h. 231.

${ }^{20}$ Abdurrakhim, Perkembangan Pemikiran dalam Bintang Tasawuf. (Jakarta: Pertja, 2001), h. 33.

${ }^{21}$ Abuddin Nata, Akhlak..., h. 232.

${ }^{22}$ Afif Anshori. Tasawuf Filsafat Syaikh Hamzah Fansuri (Jakarta: Gelombang Pasang, 2004). h. 167
} 


\section{Ittihad}

Apabila seorang sufi telah berada dalam keadaan fana, maka pada saat itu ia telah dapat menyatu dengan Tuhan, sehingga wujudiyahnya kekal atau al-Baqa. Di dalam perpaduan itu ia menemukan hakikat jati dirinya sebagai manusia yang berasal dari Tuhan, itulah yang dimaksud dengan ittihad. ${ }^{23}$

Fana adalah lenyapnya inderawi atau kebasyariahan, yakni sifat sebagai manusia biasa yang suka pada syahwat dan hawa nafsu. Orang yang telah diliputi hakikat ketuhanan, sehingga tiada lagi melihat daripada alam nyata ini, maka ia dinyatakan telah fana dalam alam makhluk. ${ }^{24}$ Sebagai akibat dari fana adalah baqa. Secara harfiah baqa berarti kekal, sedang menurut yang dimaksud para sufi, baqa adalah kekalnya sifat-sifat terpuji, dan sifat-sifat Tuhan dalam diri manusia. Karena lenyapnya (fana) sifat-sifat basyariah, maka yang abadi adalah sifat-sifat ilahiyah. ${ }^{25}$

Dengan demikian, dapatlah dipahami bahwa yang dimaksud dengan fana adalah lenyapnya sifat-sifat basyariah, akhlaq yang tercela, kebodohan dan perbuatan maksiat dari diri manusia. Sedangkan baqa adalah kekalnya sifat-sifat ketuhanan, akhlaq yang terpuji, ilmu pengetahuan dan kebersihan diri dari dosa dan maksiat. Untuk mencapai baqa ini perlu dilakukan usaha-usaha seperti bertaubat, berdzikir, beribadah, dan menghiasi diri dengan akhlaq yang terpuji. ${ }^{26}$ Dapat disimpulkan bahwa, berbicara fana dan baqa ini erat hubungannya dengan al-Ittihad, yakni penyatuan batin atau rohaniah dengan Tuhan, karena tujuan dari fana dan baqa itu sendiri adalah ittihad itu.

Pengertian ittihad sebagaimana disebutkan dalam sufi terminologi adalah penggabungan antara dua hal yang menjadi satu. Ittihad merupakan doktrin yang menyimpang dimana di dalamnya terjadi proses pemaksaan antara dua ekssistensi. Kata ini berasal dari kata wahd atau wahdah yang berarti satu atau tunggal. Jadi Ittihad artinya bersatunya manusia denganTuhan.

Dengan demikian, dalam baqa dan fana, sejalan dengan pendapat Mustofa Zahri yang mengatakan fana dan baqa tidak dapat dipisahkan

${ }^{23}$ A. Rivay Siregar, Tasawuf: Dari Sufisme Klasik Ke Neo-Sufisme, (Jakarta; RajaGrafindoPersada, 1999), h. 152.

${ }^{24}$ Mustafa Zahri, Kunci Memahami Ilmu Tasawuf, (Surabaya; Bina Ilmu,1985), h. 234.

${ }^{25}$ Abuddin Nata, Akhlaq Tasawuf (Jakarta; RajaGrafindo Persada,1996), h.232.

${ }^{26}$ Ibid, h. 223. 
dengan pembicaraan paham ittihad. Dalam ajaran ittihad sebagai salah satu metode tasawuf sebagaimana dikatakan oleh al-Baidawi "yang dilihat hanya satu wujud, sungguhpun sebenarnya yang ada dua wujud yang berpisah dari yang lain". Karena yang dilihat dan yang dirasakan hanya satu wujud, maka dalam ittihad ini bisa terjadi pertukaran peranan antara yang mencintai (manusia) dengan yang dicintai (Tuhan) atau tegasnya antara sufi dan Tuhan. ${ }^{27}$

\section{Hulul}

Secara harifah hulu/ berarti Tuhan mengambil tempat dalam tubuh manusia tertentu, yaitu manusia yang telah dapat melenyapkan sifat-sifat kemanusiannya melalui fana. Menurut keterangan Abu Nasr al-Tusi dalam al-Luma sebagaimana dikutip Harun Nasution, adalah paham yang mengatakan bahwa Tuhan memilih tubuh-tubuh manusia tertentu untuk mengambil tempat di dalamnya setelah kemanusiaan dalam tubuh itu dilenyapkan. Di mana sebelum Tuhan menjadikan makhluk, Ia hanya melihat diri-Nya sendiri, lalu Allah melihat pada zatnya sendiri dan Ia pun cinta pada zatnya sendiri, dan cinta inilah yang menjadi sebab wujud dan sebab dari banyaknya ini.

Al-Hallaj berkesmimpulan bahwa dalam diri manusia terdapat sifat ketuhanan (lahut) dan dalam diri Tuhan terdapat sifat ketuhanan (nasut). Jika sifat ketuhanan pada diri manusia menyatu dengan sifat kemanusian pada diri Tuhan maka terjadilah Hulul.

Penjelasan di atas maksudnya bahwa al-hulul dapat dikatakan sebagai suatu tahap dimana manusia dan Tuhan menyatu secara rohaniah. Dalam hal ini hulul pada hakikatnnya istilah lain dari al-ittihad sebagaimana telah disebutkan di atas. Tujuan dari hululadalah ketuhanan (lahut) menjelma kedalam diri insan (nasut) dan hal ini terjadi pada saat kebatinan seseorang insan telah suci bersih dalah menempuh perjalanan hidup kebatinan.

Demikian juga dengan manusia, mempunyai sifat kemanusian (nasut) dan mempunyai sifat ketuhanan (lahut) dalam dirinya. Paham alHallaj ini dapat dilihat dari tafsirannya mengenai kejadian Adam dalam Alquran surah al-Baqarah ayat 34: Dan (ingatlah) ketika kami berfirman

\section{6.}

${ }^{27}$ Mustafa Zahri, Kunci Memahami Ilmu Tasawuf, (Surabaya: Bina Ilmu,1985), h. 
kepada para malaikat; sujudlah kamu kepada Adam, maka sujudlah mereka kecuali Iblis; ia enggan dan takabur; dan ia termasuk golongan orang-orang kafir. (QS.2:34). Allah memberikan perintah kepada malaikat untuk sujud kepada Adam karena pada diri Adam, Allah menjelma sebagaimana Dia menjelma ( hulul) dalam diri 'Isa a.s. Allah swt menjelma dalam diri Adam, berarti Allah menjadikan Adam sesuai dengan bentukNya. Dengan adanya paham ini dapat berpangkal pada hadits yang berpengaruh besar bagi kaum sufi: "Sesungguhnya Allah menciptakan Adam sesuai dengan bentukNya." 28

Banyak para ulama yang berbeda pendapat tentang hakikat ajaran hulu/ al-Hallaj. Al-Taftazani telah berusaha menyimpulkan bahwa hululnya al-Hallaj bersifat majazi, tidak dalam pengertian yang sesungguhnya. Paham hulul al-Hallaj, menurut al-Taftazani merupakan perkembangan dan bentuk lain dari paham ittihad yang diajarkan oleh Abu Yazid. Sebenarnya antara ittihad dan hulul terdapat perbedaan. Dalam ittihad, diri Abu Yazid hancur dan yang ada hanya Allah, sedang dalam hulul hanya diri al-Hallaj yang tidak hancur. Dalam paham ittihad, yang dilihat hanya satu wujud, sedang dalam paham hulul ada dua wujud, tetapi bersatu dalam satu tubuh.

\section{Wahdat al-Wujud}

Wahdat al-wujud adalah ungkapan yang terdiri dari dua kata, yaitu wahdat dan al-wujud. Wahdat artinya sendiri, tunggal atau kesatuan, sedangkan al-wujud artinya ada. Dengan demikian wahdat al-wujud berarti kesatuan wujud. Kata wahdah selanjutnya digunakan untuk arti yang bermacam-macam. Di kalangan ulama klasik ada yang mengartikan wahdah sebagai sesuatu yang zatnya tidak dapat dibagi-bagi pada bagian yang lebih kecil. Selain itu kata al-wahdah digunakan pula oleh para ahli filsafat dan sufistik sebagai suatu kesatuan antara materi dan roh, substansi (hakikat) dan forma (bentuk), antara yang tampak (lahir) dan yang batin, antara alam dan Allah, karena alam dari segi hakikatnya qadim dan berasal dari Tuhan. ${ }^{29}$

Wahdat al-Wujud mempunyai pengertian secara awam yaitu bersatunya Tuhan dengan manusia yang telah mencapai hakiki atau

\footnotetext{
${ }^{28}$ Asmaran, Pengantar..., h. 309.

${ }^{29}$ Abd. Hakim Hasan, At-Tasawuf Asy'ir fi al-Arabi, (Cairo: Maktabah Anglo Masyriah, 1954), h. 19.
} 
dipercaya telah suci. Pengertian sebenarnya adalah merupakan penggambaran bahwa Tuhan-lah yang menciptakan alam semesta beserta isinya. Dia-lah sang Khalik, Dia-lah yang telah menciptakan manusia, Dialah Tuhan dan kita adalah bayangannya. Dari pengertian yang hampir sama, terdapat pula kepercayaan selain wahdatul wujud, yaitu wahdatul syuhud yaitu kita dan semuanya adalah bagian dari dzat Tuhan.

Wahdatul wujud sebenarnya adalah suatu ilmu yang tidak disebarluaskan ke orang awam. Sekalipun demikian, para walilah yang mencetuskan hal tersebut. Karena sangat dikhawatirkan apabila ilmu wahdatul wujud disebarluaskan akan menimbulkan fitnah dan orang awam akan salah menerimanya. Wali yang mencetuskan tersebut contohnya adalah al-Hallaj dan Ibn Arabi. Meskipun demikian, para wali tersebut tidak pernah mengatakan dirinya adalah tuhan dan mereka tetap dikenal sebagai ulama alim.

Syaikh Sa'id Fudah berkata: Adapun wusul menurut golongan sufi yang berpaham wahdatul-wujud adalah penzahiran bahwa wujud kita ialah 'ain wujud Tuhan. Maka, ini adalah suatu penzahiran ittihad wujud kita dengan wujud Tuhan. Adapun wusul menurut golongan sufi yang beraqidah ahlus-sunnah wal jamaah ialah beri'tiqad dengan kefakiran makhluk kepada Tuhan, dalam masa yang sama mengekalkan wujud kita berlainan dengan wujud Tuhan, namun tiada ittihad dalam ah/ussunnah. ${ }^{30}$

\section{Isyraq}

Kata isyraq dalam bahasa Arab berarti sama dengan kata iluminasi dan sekaligus juga cahaya pertama pada saat pagi hari seperti cahayanya dari timur (sharq). Tegasnya, isyraqi berkaitan dengan kebenderangan atau cahaya yang umumnya digunakan sebagai lambang kekuatan, kebahagiaan, keterangan, ketenangan, dan lain-lain yang membahagiakan. Lawannya adalah kegelapan yang dijadikan lambang keburukan, kesusahan, kerendahan dan semua yang membuat manusia menderita. Timur tidak hanya berarti secara geografis tetapi awal cahaya, realitas. ${ }^{31}$

${ }^{30}$ Hasan, At-Tasawuf..., h. 21.

${ }^{31}$ Seyyed Hossein Nasr, Intelektual Islam Teologi, Filsafat dan Gnosis, terj, Suharsono dan Jamaluddin MZ, (Yogyakarta: CIIS Press, 1995), h. 75. Sebagai bahan bandingan dalam hal arti isyraqi dapat dilihat juga dalam, A. Khudori Shaleh, Wacana Baru Filsafat Islam, (Yogyakarta: Pustaka Pelajar, 2004), h. 119. Dan Taufik Abdullah, 
Konsep tasawuf al-isyraq barangkali adalah tipe tasawuf falsafi yang paling orisinil di antara konsep-konsep tasawuf yang sealiran perkiraan ini cukup beralasan mengingat, bahwa Suhrawardi al-Maqtul sebagai konseptornya. Al-Isyraq berarti bersinar atau memancarkan cahaya dan nampaknya searti dengan al-kasyf. Akan tetapi bila dilihat pada inti ajaran ini, maka al-Isyraq lebih tepat diartikan penyinaran atau illuminasi. Menurut Suhrawardi, sumber dari segala yang ada iala cahaya yang mutlak ia disebut dengan nurul al-anwar, mirip matahari. ${ }^{32}$

Tokoh aliran Isyraq adalah Syihabuddin Yahya bin Hafash Suhraward. Sejak kecil ia telah belajar agamadan menghafal Al-Qur`an kemudian belajar di Maraghah berguru dengan Imam Mahyuddin Al Jilli, dilanjutkan dengan belajar kepada Zahiruddin Al Qari di Asfahan, dan diteruskan dengan belajar kepada Al Mardini.

\section{Kesimpulan}

Tasawuf falsafi adalah tasawuf yang ajaran-ajarannya memadukan antara visi mistis dan visi rasional pengasasnya. Berbeda dengan tasawuf akhlaki atau sunni, tasawuf falsafi menggunakan terminologi filosofis dalam pengungkapannya serta berasal dari bermacam-macam ajaran filsafat yang telah mempengaruhi para tokohnya.

Tasawuf falsafi muncul dengan jelas dalam khazanah Islam sejak abad keenam hijriyah meskipun para tokohnya baru dikenal seabad kemudian. Sejak saat itu, tasawuf jenis ini hidup dan berkembang, terutama di kalangan para sufi yang juga filosof, sampai menjelang akhirakhir ini. Adanya pemaduan antara tasawuf dan filsafat dalam ajaran tasawuf falsafi menyebabkan ajaran-ajaran tasawuf jenis ini bercampur dengan sejumlah ajaran filsafat di luar Islam, seperti Yunani, Persia, India, dan agama Nasrani. Akan tetapi, orisinalitasnya sebagai tasawuf tetap tidak hilang.

Ciri umum tasawuf falsafi adalah ajarannya yagn samar-samar akibat banyaknya istilah khusus yang hanya dapat dipahami oleh mereka yang memahami ajaran tasawuf jenis ini. Tasawuf falsafi tidak dapat dipandang sebagai filsafat karena ajaran dan metodenya didasarkan pada rasa $(d z u q)$, tetapi tidak dapat pula dikategorikan sebagai tasawuf dalam

dkk, (edt), Ensiklopedi Tematis Dunia Islam Pemikiran dan Peradaban, (Jakarta: Ichtiar Baru van Hoeve, 1995), h. 215.

32 Ziai, Hussein, Suhrawardi dan Filsafat I/uminasi, terj. Alif Muhammad dan Munir, (Bandung: Zaman, 1998), h. 78. 
pengertiannya yang murni, karena ajarannya sering diungkapkan dalam bahasa filsafat dan lebih berorientasi pada panteisme. Adapun beberapa tema ajaran tasawuf falsafi berkenaan dengan fana', baqa, ittihad, hulul dan isyraq.

\section{DAFTAR PUSTAKA}

A. Khudori Shaleh, Wacana Baru Filsafat Islam, Yogyakarta: Pustaka Pelajar, 2004.

A. Rivay Siregar, Tasawuf: Dari Sufisme Klasik Ke Neo-Sufisme, Jakarta; RajaGrafindoPersada, 1999.

Abd. Hakim Hasan, At-Tasawuf Asy'ir fi al-Arabi, Cairo: Maktabah Anglo Masyriah, 1954.

Abdurrakhim, Perkembangan Pemikiran dalam Bintang Tasawuf, Jakarta: Pertja, 2001.

Abuddin Nata, Akhlak Tasawuf, Jakarta: Grafindo Persada, 2006

Afif Anshori. Tasawuf Filsafat Syaikh Hamzah Fansuri, Jakarta: Gelombang Pasang, 2004.

Alwi Shihab, Islam Sufistik: "Islam Pertama" dan Pengaruhnya hingga Kini di Indonesia, Bandung: Mizan 2001.

Amin Syukur, Tasawuf Kontekstual, Yogyakarta: Pustaka Pelajar, 2003.

Annemarie Schimmel, Dimensi Mistik dalam Islam, Terj. S. Djoko Damono dkk, Jakarta, Pustaka Firdaus, 2003.

Anwar, Rosihon. Ilmu Tasawuf, Bandung, Pustaka Setia, 2006.

Asmaran As., Pengantar Studi Tasawuf, Jakarta: Rajawali Pers, 1996.

Fazlur Rahman, Islam, Chicago: University of Chicago Press, 1979.

Ibn Khaldun, The Muqaddimah, Trans. Franz Rosenthal, Princeton: Princeton University Press, 1989. 
J. Spencer Trimingham, The Sufi orders in Islam, New York: Oxford University Press, 1973.

Jamil, Cakrawala Tasawuf, Ciputat: Gaung Persada Press, 2004.

Julian Baldick, Mystical Islam an Introduction to Sufism, New York: New York University Press, 1992.

Khaja Khan; Mysticism in the World is as old as its Hills. Adam was perphaps the first mystic who had direct illumination, lihat Khaja Khan, Studies in Tasawuf, Pakistan: Lahore, 1990.

Komaruddin Hidayat, Wahyu di langit Wahyu di Bumi, Jakarta: Paramadina, 2003.

Lynn Wilcox, IImu Jiwa Berjumpa Tasawuf, terj. I.G. Harimukti Bagoesoka, Jakarta: Serambi, 2003.

M. Sholihin, Melacak Pemikiran Tasawuf di Nusantara, Jakarta: Raja Grafindo Persada, 2005.

Mustafa Zahri, Kunci Memahami Ilmu Tasawuf, Surabaya; Bina Ilmu, 1985.

Seyyed Hassein Nasr,"Al-Quran sebagai Fondasi Spiritualitas Islam", Ensiklopedi Tematis Spiritualitas Islam, terj. Rahmani Astuti, ed. Seyyed Hassein Nasr, Vol. I, Bandung: Mizan, 2003.

Seyyed Hossein Nasr, Intelektual Islam Teologi, Filsafat dan Gnosis, terj, Suharsono dan Jamaluddin MZ, Yogyakarta: CIIS Press, 1995.

Taufik Abdullah, dkk, edt), Ensiklopedi Tematis Dunia Islam Pemikiran dan Peradaban, Jakarta: Ichtiar Baru van Hoeve,1995.

Ziai, Hussein, Suhrawardi dan Filsafat I/uminasi, terj. Alif Muhammad dan Munir, Bandung: Zaman, 1998. 